Article

\title{
Disrupting Dialogue? The Participatory Urban Governance of Far-Right Contestations in Cottbus
}

\author{
Gala Nettelbladt ${ }^{1,2}$ \\ ${ }^{1}$ Leibniz Institute for Research on Society and Space, 15537 Erkner, Germany, E-Mail: gala.nettelbladt@leibniz-irs.de \\ 2 Department of Urban and Regional Sociology, Institute of Social Sciences, Humboldt-University of Berlin, \\ 10117 Berlin, Germany
}

Submitted: 29 October 2020 | Accepted: 19 January 2021 | Published: 27 April 2021

\begin{abstract}
This article investigates how municipal governments negotiate far-right contestations through the format of citizens' dialogues and contemplates to what extent they disrupt established assumptions about participatory urban governance. In doing so, I want to contribute to emerging scholarship on reactionary responses to migration-led societal transformations in cities via scrutinising their effects on institutional change in participatory practices. Building on participatory urban governance literature and studies on the far right in the social sciences, I argue that inviting far-right articulations into the democratic arena of participation serves to normalise authoritarian and racist positions, as the far right's demand for more direct involvement of 'the people' is expressed in reactionary terms. I will show how this applies to two prominent notions of participation in the literature, namely, agonistic and communicative approaches. This argument is developed through an explorative case study of two neighbourhood-based citizens' dialogues in Cottbus, East Germany, which the municipal government initiated in response to local far-right rallies. While a careful reading of these forums reveals productive potentials when the issue of international migration is untangled from context-specific, socio-spatial problems in the neighbourhoods, my analysis also shows how the municipality's negotiation of far-right contestations within the citizens' dialogues serves to legitimise far-right ideology. I find that to negotiate today's societal polarisation, municipal authorities need to rethink local participatory institutions by disentangling these complex dynamics and reject far-right contestations, while designing dialogues for democratic and emancipatory learning.
\end{abstract}

\section{Keywords}

agonism; cities; communicative planning theory; far right; local democracy; municipal government; participation; populism; racism; urban governance

\section{Issue}

This article is part of the issue "Migration-Led Institutional Change in Urban Development and Planning" edited by Robert Barbarino (TU Dortmund University, Germany), Charlotte Räuchle (Free University Berlin, Germany) and Wolfgang Scholz (TU Dortmund University, Germany).

(C) 2021 by the author; licensee Cogitatio (Lisbon, Portugal). This article is licensed under a Creative Commons Attribution 4.0 International License (CC BY).

\section{Introduction}

Discussions on how migration initiates institutional change in cities often focus on the emancipatory potential of participatory practices such as urban citizenship or how co-production strategies between civil society organisations and public administrations can foster inclusive policies. Scholars, however, have neglected changing forms of participation instigated by reac- tionary responses to migration-led societal transformation. Addressing this gap, this article attends to far-right contestations of such transformations in cities and asks how they disrupt established assumptions about participatory urban governance. The contemporary rise of far-right politics poses new challenges to municipalities across the globe, fuelling racism and xenophobic attacks on marginalised groups - calling into question an increasingly plural and diverse urban order. Some scholars argue 
that the growing influence of far-right actors confronts urban practitioners (policymakers, planners, advocates, and organisers) with the practical question of how to deal with a divided public (Rivero, Sotomayor, Zanotto, \& Zitcer, 2020). Others claim that "the 'invisible' contract governing a multicultural...city is under threat" (Khakee, 2020, p. 179).

In Germany, many municipal governments have used public citizens' dialogues as an instrument to react to far-right rallies, which have drastically increased since the long summer of migration in 2015 (DIFU, 2019). However, studies examining such practices dealing with far-right contestations are scarce. How are far-right contestations negotiated through participatory processes? To what extent do they disrupt established assumptions about participation in the literature? Based on case study research in the East German city of Cottbus, I hope to answer these questions.

Promoting people's participation in urban processes has long been a key issue in discussions about urban governance. This is aimed at recognising people's voices in city-making, which are viewed as a crucial element to carry out urban development in a more effective, sustainable, and just way (Forester, 1989; Healey, 1992; Innes \& Booher, 2004). However, so-called communicative approaches to participation have been widely problematised, particularly regarding their inability to re-negotiate power asymmetries in extremely unequal urban contexts (Cornwall, 2002; Fainstein, 1999; Flyvbjerg, 1996; Huxley \& Yiftachel, 2000; Miessen, 2011; Purcell, 2006; Roy, 2009). One strand of critique derives from agonistic approaches to participation, stipulating that inclusive urban governance processes need to start not from a position of trying to resolve conflict in order to achieve consensus, but from a position of acceptance of uncertain situations and continual dissent and opposition (Bäcklund \& Mäntysalo, 2010; Beaumont \& Nicholls, 2008; Gualini, 2015; Pløger, 2004; Verloo, 2018). Ultimately, they view conflict as a productive resource in people's involvement in city-making. In this article, I want to build on these debates, exploring how both approaches are put to the test in times of far-right contestations. To do so, I bring the literature on participatory urban governance into conversation with studies on the far right in the social sciences, which reveal the ambiguous participatory agenda of far-right politics and point towards mechanisms of contestations that are deeply reactionary.

Referring to these discussions, I examine the negotiation of far-right contestations through state-led citizens' dialogues in Cottbus, which the municipal government launched in response to a series of far-right rallies that took place in 2018. Analysing how these public dialogues were designed at the nexus of communicative/agonistic approaches to participation, I propose that such participatory practices can reveal small windows of democratic opportunity in a climate of rising reactionary politics. This can happen if and when they help to dis- sect racialised conflicts, disentangling the issue of international migration from context-specific neighbourhood problems. However, in a second step I add complexity to this argument, demonstrating how open-ended participatory formats aimed at fostering dialogue between long-term residents supportive of far-right politics and municipal government representatives can serve to normalise far-right agendas. Thus, I argue that such citizens' dialogues escape communicative and agonistic assumptions about participatory processes alike, as they offer a platform for reactionary articulations that ultimately disrupt democratic dialogue.

The article is structured as follows: I start by exploring the debate on participatory urban governance, introducing critiques of communicative approaches and highlighting agonistic perspectives as one prominent alternative. I go on to define far-right contestations by drawing on social science literature about the far-right and identify the far-right's ambiguous participatory agenda. Suggesting that the contemporary rise in far-right politics demands a new perspective on participatory processes, I propose to bring these two literatures into conversation. Third, I introduce the city of Cottbus and reflect upon the methods used in my qualitative fieldwork. Subsequently, I analyse two citizens' dialogues in their respective neighbourhoods-Sachsendorf and Sandow-in detail. After presenting this case, I conclude by discussing the need to reconfigure participatory processes that aim to negotiate far-right contestations (regarding the design of both format and content) if they are to remain within the remit of the democratic arena.

\section{Conceptual Framework}

\subsection{Participatory Urban Governance: Tracing a Manifold Debate}

Urban studies scholars have long approached participatory urban governance from distinct conceptual angles. As it would go beyond the scope of this article to review this rich debate in detail (for an overview see Frediani \& Cociña, 2019), I focus on two approaches that are rooted in larger discussions in social theory between Jürgen Habermas and Chantal Mouffe, namely, the notions of 'communicative' and 'agonistic' engagement. First, communicative approaches to participatory urban governance were put forward by authors such as Patsy Healey, John Forester, and Judith Innes in the 1980s. The conceptual assumption of this 'communicative turn' in participatory urban governance is that if rules are designed to guarantee equality for deliberating parties, participants can likely find a rational consensus (Forester, 1989; Healey, 1992; Innes \& Booher, 2004). This perspective was developed to address the undeniable limitations of positivist, comprehensive-rationalist governance tools in city-making. Instead, it gives "priority to the process through which decisions are made and stresses the significance of undistorted speech, [allowing] the relation 
of group identities and the explicit recognition of difference...to define a desirable set of social relations" (Fainstein, 1999, pp. 259-260).

For the last decades, these strategies have figured prominently among researchers and practitioners alike, using such relational understandings of participatory processes as a tool to address the complex socio-spatial dynamics of city-making, and attempting to recognise people's voices within this process. However, criticism of this 'communicative turn' has been widely advocated by scholars from different disciplines, causing the publication of books with titles such as Participation: The New Tyranny? (Cooke \& Kothari, 2001) or The Nightmare of Participation: Crossbench Praxis as a Mode of Criticality (Miessen, 2011). These critiques draw attention to the need to unpack the different conditions within which participation is practiced, warning of the foregrounding of local actions that leaves structural processes unchallenged (e.g., Arnstein, 1969; Cornwall, 2002; Fainstein, 2010; Flyvbjerg, 1996; Purcell, 2006). More specifically, the Habermas-inspired communicative approach is criticised for "privileg[ing] communication at the expense of its wider social and economic contexts" (Huxley \& Yiftachel, 2000, p. 333). In this vein, masking deliberation as neutral strategy provides "an extremely attractive way for neoliberals to maintain hegemony while ensuring political stability" (Purcell, 2009, p. 140). Consequently, critiques have highlighted that the emphasis of communicative approaches on consensus building hides social complexities, diversities (Miraftab, 2019) - and conflict.

Agonist approaches to participation have directly emerged from this last criticism, acknowledging conflict "as a constitutive element of social relations [in the city] and as a source of their strength and ability to innovate" (Gualini, 2015, p. 3). Inspired by Chantal Mouffe's theory of 'agonistic pluralism' (Mouffe, 2000), this perspective politicises ideas of plurality and inclusion in participatory processes (Swyngedouw, 2011; Wilson \& Swyngedouw, 2015). Conflict is viewed as a productive force, potentially transforming antagonism (conflict between enemies) into agonism: "A relationship between adversaries, not enemies" (Mouffe, 2000, p. 102). Hence, city-making "should ideally be a place for strife about legitimate options and meanings on the road towards reasonable and commonly agreed solutions or among mutual adversaries" (Pløger, 2004, p. 72), whereby collective passion (rather than rationalist deliberation) is viewed as a channel through which citizens articulate themselves (Amin, 2002; Beaumont \& Nicholls, 2008; Mouffe, 2000; Verloo, 2018).

Thus, agonistic notions understand conflict as radically different to the communicative ideal, namely "as one that is neither physical nor violent, but a friction that emerges on a content and productive level, a conflict played out within the remit of the democratic arena" (Miessen, 2011, p. 101). However, Bäcklund and Mäntysalo (2010) have argued that even though the paradigmatic shift from communicative to agonistic par- ticipation has sparked fruitful theoretical debates at the nexus of planning and democratic theory, little scholarly attention has been paid to the empirical facets of this shift. They lament that this contributes to widening the gap between theory and practice. Based on their own empirical research, they point to the tensions between agonistic theory as municipal Leitbild and urban practice. Specifically, they find that both theories often co-exist in the participatory practices offered by city administrations, generating 'institutional ambiguity' (Bäcklund \& Mäntysalo, 2010, p. 348), whereby new conceptual ideas about participatory urban governance are merely imposed on top of existing administrative and institutional structures, leading to 'shallow practical reform' (Bäcklund \& Mäntysalo, 2010). In a similar vein, others have argued for the need to move beyond the communicative and agonistic divide in participatory practices and, indeed, combine both conceptual perspectives in urban analysis that is more connected to empirical research (Beaumont \& Loopmans, 2008; Bond, 2011; Legacy, Metzger, Steele, \& Gualini, 2019; Van Wymeersch, Oosterlynck, \& Vanoutrive, 2019).

Against this backdrop, I want to contemplate to what extent these established assumptions about participatory processes are disrupted when conflicts escape the democratic arena and can no longer be viewed as moments of communicative or agonistic negotiation in the city. What happens if urban actors bring far-right articulations to the negotiation table? And how can we rethink modes of participation in cities facing this challenge?

\subsection{The Ambiguous Participatory Agenda of the Far Right and Its Mechanisms of Contestations}

To understand the challenges the rise of reactionary politics poses to participatory urban governance processes, I draw on insights from social science literature about the far right, shedding light on the far right's ambiguous stance towards public participation and its modes of contestation. In doing so, I want to contribute to the debate on participatory urban governance by stipulating that the rise of far-right politics demands a new perspective on participatory practices. Let me first clarify some terms, however: I purposefully refer to the 'far right,' not 'right-wing populism' to capture the contemporary surge of reactionary politics. In doing so, I follow political scientists who have argued that to label contemporary reactionary currents as 'populist' is to fundamentally downplay their threat to democratic institutions (for detailed terminological debates see Mondon \& Winter, 2020; Mudde, 2007). The far right is used as an umbrella term to recognise common traits between reactionary political actors, including the extreme right, the (populist) radical right, and (neo)-fascists (Mudde, 2019), suggesting that what they hold in common are antipluralistic, racist, anti-feminist, nationalist, and authoritarian attitudes and ideologies. This core element of the far right entails the belief that "the nation state should 
be inhabited only by native people; and that societies must be strictly ordered and infringement severely sanctioned" (Mudde, 2007, pp. 18-23) However, in the vast literature on this contested subject, a dominant position distinguishing the 'extreme' from the 'radical' variants of far-right politics with regards to the different democratic elements that constitutes them. While the extreme right is essentially hostile towards constitutional democratic principles, the radical right holds oppositional attitudes towards liberal democracies (Mudde, 2019, p. 8).

Concerning the far right's perspective on participatory practices, acknowledging these two different political strands within it is crucial. First, the extreme right essentially rejects the foundations of democracy, i.e., popular sovereignty and majority rule. Second, the radical right accepts the essence of democracy in the name of 'the people,' albeit while opposing key elements of liberal democracies, i.e., minority rights, rule of law, and the separation of powers (Barney \& Laycock, 1999). Further, radical-right leaders promote a 'plebiscitarian linkage' between the executive and 'the people,' which refers to the idea that they tend to act as the embodiment or more efficient executor of the general will of 'the people' once in government (Canovan, 2002, p. 34).This points towards the tension between the radical right's rhetoric of more direct participation and the actual democratic aspirations embodied therein (Canovan, 1999, p. 14; Paxton, 2019), essentially failing to grant citizens control over decision-making processes (Barney \& Laycock, 1999). In practice, these opposing strands often overlap, rendering the participatory agenda of far-right actors profoundly ambiguous (Canovan, 2002, p. 34). The entangled heterogeneity of far-right participatory articulations also alludes to the far right's multifarious organisational structures, with a majority of contemporary far-right actors often simultaneously engaging in the electoral and the protest arenas (Castelli Gattinara \& Pirro, 2019; Rucht, 2018). Thus, there are emerging publications that address the interconnection between the success of far-right parties and right-wing street movements (Froio, Gattinara, Bulli, \& Albanese, 2020), which also applies in the case of Cottbus, as I will illustrate subsequently.

To operationalise my analysis of the negotiation of far-right contestations by municipal governments, I borrow from German sociologist Heitmeyer to define three mechanisms of contestation. According to him, the core aim of contemporary far-right politics is to contest and destabilise the institutions that uphold the tenets of open societies in liberal democracies. Its ultimate goal is to install a new, authoritarian order (Heitmeyer, 2018, p. 239) by way of, first, promoting a 'dichotomous world view' in an increasingly complex world, presenting a supposedly tempting alternative of clarity and control. This often takes the form of imagining 'the people' as a homogenous entity whose identity, ideas, and will can be fully represented, versus the 'elite.' Another divisive dichotomy concerns the racist distinc- tion between 'the people' and the 'alien other' (in contemporary Western societies most notably immigrants, Muslims, or refugees - not the 'native elite'). Second, farright politics advance the 'emotionalization' of societal problems and politics. This 'emotionalised politicisation' (Heitmeyer, 2018, p. 252) is an effective strategy to instigate a sense of loss among supporters of the far right, e.g. linking structural problems like rising social inequalities to feelings of fear. Finally, far-right politics use 'control' as a means of power to install a supposedly new sense of order, by way of returning to an imagined 'old' order. As such, far-right solutions are promoted as attempts to 'gain back control' for individuals and a subset of society alike. In the next section, I examine how these mechanisms of far-right contestations are negotiated through participatory processes in the case of Cottbus.

\section{Situating Cottbus}

An hour and a half by train from Berlin, the mid-sized city of Cottbus is located in the federal state of Brandenburg, close to the Polish border (see Figure 1). Like many cities in East Germany, it experienced urban shrinkage since the 1990s, facing economic and demographic decline (Bernt, 2009) after German reunification in 1990 came with a neoliberal 'shock therapy' (Grubbauer \& Kusiak, 2012 , p. 13), precipitating the drastic reorganisation of the region's economic system. In 1990, Cottbus still had

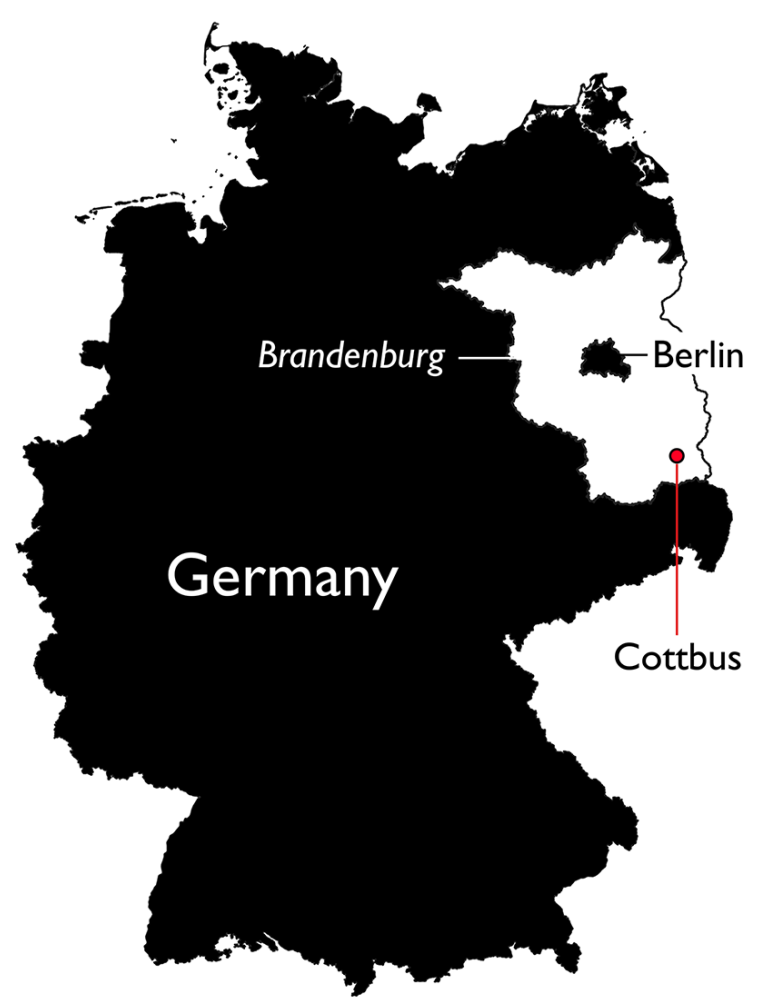

Figure 1. The location of the case study, Cottbus (in Brandenburg, Germany). The map is oriented North. Source: German Federal Agency for Cartography and Geodesy (2021). 
a population of approximately 134,000 (Stadt Cottbus, 2019b). Throughout the 1990s and early 2000s, this number dropped drastically, reaching a historic low of 99,500 in 2012 (Stadt Cottbus, 2019c). Throughout the former German Democratic Republic up until now, the coal-mining industry was the most important economic sector in the region (IASS, 2018). However, the city's unemployment rate has long been one of the highest in Germany, today it is at $7.4 \%$, as compared to the national average of 5.6\% (Stadt Cottbus, 2019a). Against this backdrop, the city is slowly growing again due to the arrival of international migrants that began in 2015. In 2019, approximately $8 \%$ of Cottbus' population were foreigners compared to $3.4 \%$ in 2011 (Stadt Cottbus, 2019b). Accordingly, in 2016 the city had just over 100,000 inhabitants. The influx of international migrants has mainly consisted of Syrian refugees, whose absolute number comprised 2,472 in 2018 (Stadt Cottbus, 2019b). These refugees largely moved to the city's peripheral prefabricated housing estates that had been built under socialism, which are also characteristic for Sachsendorf and Sandow, the two neighbourhoods that form the subject of my study. Both neighbourhoods were particularly hit by the city's demographic decline and part of the national redevelopment plan Stadtumbau Ost (Urban Restructuring East) focused on demolition (Liebmann, Hagemeister, Haller, \& Nelle, 2010). In a nutshell, Sachsendorf and Sandow consequently underwent symbolic marginalisation and became increasingly home to elderly lower social classes (Kabisch \& Peter, 2014).

\subsection{A note on Research Methods}

My subsequent discussion of two citizens' dialogues in these neighbourhoods is based on a qualitative and explorative single-case study of the city of Cottbus (Yin, 2014). The empirical data used for this article comprises participant observation, 16 semi-structured interviews and document analysis. First, I participated in several neighbourhood-based citizens' dialogues that took place across the city during 2018 and 2019. In addition to these in-person observations, I watched and transcribed the video recordings of the events in Sachsendorf and Sandow, which were made available on the city's website. This facilitated my data analysis, as it allowed to systematically code the different contributions made by residents. I chose to examine the neighbourhoods of Sachsendorf and Sandow in detail for two reasons: On one hand, both are attractive neighbourhoods for refugees due to low rents and have experienced rapid diversification over the last years (for a thorough analysis for the transformation of peripheral neighbourhoods in East Germany due to the arrival of refugees, see El-Kayed, Bernt, Hamann, \& Pilz, 2020). On the other hand, it is those neighbourhoods where voter turnout for the far-right party Alternative for Germany (AfD) has been the city's highest, encompassing $23,6 \%$ and $26,5 \%$ respectively in 2019's municipal elections (Stadt Cottbus, 2019d; for more insights on the socio-spatial conditions of the AfD's electoral success see Förtner, Belina, \& Naumann, 2020).

Second, I returned to Cottbus in the summer months of 2020 to conduct interviews with government officials, politicians involved in the organisation of the participatory formats, local social workers and residents that had participated in the dialogues. I conducted these interviews during the global Covid-19 pandemic, which posed specific challenges, as we have explored elsewhere (Nettelbladt \& Reichle, in press). Third, I complemented these investigations with the analysis of textual resources, such as development plans from the city administration. Additionally, I scrutinised the websites of local far-right actors to obtain an understanding of the envisioned strategies and motives they had to attend the citizens' dialogues. Lastly, newspaper articles covering the citizens' dialogues provided another view of the way the participatory strategies were perceived in Cottbus and beyond.

\subsection{Cottbus as a Bastion of Far-Right Organisation}

Scholars of far-right politics and activist working on the prevention of far-right politics have characterised Cottbus as a place par excellence for the mobilisation of the far-right in Germany. Since the 1990s, Cottbus has served as a far-right hub, connecting 'concerned citizens' with far-right intellectuals who have managed to activate long-established neo-Nazi networks in the region. A particularly active actor has been the local extremeright movement Zukunft Heimat, which holds close ties with völkisch authoritarian groups, as well as the local branch of the AfD, which had gained $27 \%$ in the municipal elections in 2019 (Fröschner \& Warnecke, 2019, p. 7). This melange of far-right actors points to the porous borders between parties and movements (Froio et al., 2020). For example, since October 2020, the founder of Zukunft Heimat serves as chairman of the AfD in Brandenburg's state parliament. This far-right presence in the city has harmful consequences for the far-right's targets: 2016 alone saw 41 officially registered far-right violent attacks in Cottbus, the largest number in the state of Brandenburg (Opferperspektive, 2021). Further, the municipal government in Cottbus has consistently downplayed this threat and was referring to the city's violent far-right youth groups a 'passing fad' in the 1990s (Emcke, 1999).

Between 2017 and 2018, Cottbus witnessed fortnightly rallies organised by Zukunft Heimat, gathering between 2,000-3,000 people protesting against the right to asylum, the influx of international migrants, the 'political elite,' 'fake news,' and 'gender ideology.' Speeches given at these rallies proclaimed racist and anti-Semitic positions, as well as conspiracy theories (Botsch \& Schulze, 2018), and the atmosphere was dominated by the hostile and aggressive mood of participants carrying signs demanding the abolition of the Federal 
Republic (Botsch \& Schulze, 2018). During the following months, migration became a particularly politicised topic in Cottbus, with international media outlets reporting on far-right violent attacks on refugees (Brady, 2018; Buck, 2018), while local far-right actors successfully shaped this media discourse to connect migration to questions of security. Long-term residents complained about the municipal government's failure to 'protect' them from the alleged effects of migration, which briefly pressured the mayor into declaring an 'immigration ban' that was, however, not actualised (Rafael, 2018).

It is in this context, that the mayor (Christian Democratic Union of Germany) announced the citizens' dialogues as a direct response by the municipal government to the far-right rallies in a meeting of the city council in April 2018 (Stadt Cottbus, 2018). During this meeting, the reason for the envisaged dialogues was clearly articulated by party members from the Greens, die Linke, and the Social Democratic Party of Germany as being the far-right rallies, as the following statement by a member of the Greens illustrates: "We welcome the mayor's effort of launching a dialogue among all Cottbussers...where we should urgently address the far-right tendencies in our city" (Stadt Cottbus, 2018). Meanwhile, members of National Democratic Party of Deutschland and AfD took the position of far-right protestors. Interestingly though, when the dialogues started in May 2018, the initiators did not directly address the original cause. Rather, the intention for the participatory forums was framed as an opportunity to "simply get into an exchange with each other about the problems in our city, no matter if we [residents and municipal government] agree or not," as the mayor proclaimed during the first forum.

\subsection{The Citizens' Dialogues: Aim, Design, Participants}

Thus, the official reason for organising the dialogues was to ameliorate the perceived uneasy relationship between residents and the municipal government, based on an "observed lack of trust in state institutions" (Chairman of the City Council, Citizens' Dialogue Sachsendorf) among residents. Accordingly, the goal of this participatory process was not to arrive at a concrete planning outcome like, for instance, a development plan. Rather, participation in the citizens' dialogues was viewed as an end in itself. In this sense, the citizens' dialogues were designed with both communicative and agonistic elements in mind: First, regarding the consensus/conflict nexus, as I will illustrate, the organisers repeatedly stressed that the participatory forums should be a space for "disagreeing views" (thus, siding with agonism's emphasis on conflict), while also highlighting the need for "the common ground of informed arguments" (Interview, civil servant, August 17, 2020), alluding to the communicative emphasis on deliberative consensus. Second, regarding the nexus of rationality/emotions, they claimed that "we should keep with the facts, but not abandon emotions" (Stadt Cottbus, 2018); thus, simultaneously calling on rational and passionate debate.

Asked why this aim could not be achieved through existing participatory structures, one civil servant claimed:

We basically felt that the existing participatory institutions [e.g., townhall meetings or consultation hours for residents] did not suffice to deal with the situation. We wanted to talk differently with residents who did not feel like they were being heard. (Interview, August 26, 2020)

This quotation illustrates the logic underpinning the municipality's strategy: By means of designing a forum where "everyone has to tolerate each other's opinion" (Moderator, Interview, August 27, 2020) officials hoped to reduce people's dissatisfaction. This entailed the assumption that, "if protestors' concerns are taken seriously by the municipal government, far-right mobilisations by local extreme-right groups become less attractive" (Moderator, Interview, August 27, 2020).

The municipality's decision to locate the citizens' dialogues at the neighbourhood level was explained by one of the moderators in Sachsendorf: "It is the neighbourhoods where the problems, questions, worries, needs, and challenges are that are at the centre of our discussion" (Citizens' Dialogue Sachsendorf).

Each event followed the same top-down set-up: The mayor and chairman of the city council were seated on a stage and residents were invited to sit in front of them. Leading personnel of the local administration participated, including staff from the Ordnungsamt (municipal office of public order), the department of urban planning, and the department of social affairs. Additionally, the staff of the local immigration office, the police, and the municipal housing company were present. All events were moderated by two professional mediators, who were mostly in charge of facilitating the speaking order, which was structured in a hierarchical question-answer format that lasted two hours. At the beginning, the moderators laid out formal rules of discussion, telling people to raise their hands to contribute and to not interrupt others. Afterwards, residents were allowed to stay and have one-to-one conversations with municipal representatives. In both neighbourhoods, the dialogues took place in local schools and approximately 140 residents showed up.

However, it is striking that residential groups with an international background hardly participated. In Sandow, a total of 33 residents spoke up, all of them longterm residents of the city. In Sachsendorf, 3 out of 24 residents that spoke publicly presented themselves as refugees. Furthermore, it is not clear how many far-right activists participated, as the events were open to all residents in the respective neighbourhoods. Based on my participant observations and document analysis, it 
appears that there was no pre-organised effort to agitate the events, however, the majority of long-term residents promoted far-right ideology, perhaps mirroring the high electoral success of the AfD (see Section 3.2). It is important to point out, though, that there were other long-term residents that showed solidarity with residential newcomers.

\section{Productive Conflict or Normalisation of Far-Right Ideology?}

The motives and logic underpinning the design of citizens' dialogues in Cottbus explored above indicate an attempt by officials to create a space of agonistic disagreement, while maintaining a deliberative order. Even though they were designed in a top-down manner, the forums were agonistically framed as an open-ended process, whereby the coming together of residents and the municipal government constituted the primary goal.

\subsection{Moments of Agonistic Conflict}

Indeed, at times, this design allowed for the emergence of the transformative potential of conflict. This happened when racialised neighbourhood conflicts were untangled, separating the issue of international migration from socio-economic urban problems. For example, a prominent topic was the issue of housing. Most refugees in Sachsendorf and Sandow now live in apartments owned by the city's housing company. In this context, long-term residents were concerned "if there will still be affordable housing in the future" (Citizens' Dialogue, Sandow), implying that it was 'the refugees' taking away affordable housing. As representatives of the housing company were present, these worries could quickly be removed, as they could point to the statistics on vacant flats. Another example was the issue of litter in public spaces. Several residents blamed refugees for 'not cleaning up after themselves,' promoting a racist logic of 'dirty foreigners,' as this comment by a long-term resident illustrates: "I live directly next to them refugees]. And I don't even want to start talking about the litter. It's everywhere! It's everywhere! Is nobody teaching them how to clean up after themselves?" (Citizens' Dialogue, Sachsendorf).

However, another long-term resident countered this racist framing, directly challenging the claim by pointing to the "typical German litter" in the neighbourhood, stating that trash "is not an attribute of the refugees" (Citizens' Dialogue, Sachsendorf). Thus, I argue that the dialogues became productive whenever participants or municipal actors managed to stir the debate away from a narrow focus on alleged migration-induced problems. This certainly underlines the usefulness of negotiations at the neighbourhood scale, allowing for the discussion of concrete socio-spatial problems when dealing with broader societal polarisation trends. In the case of Cottbus, this discussion can be read in the context of the neighbourhoods' histories of reconstruction. Yet, during the dialogues topics such as housing or public space remained underrepresented. Instead, what dominated the debates was the instrumentalization of migration (Radvan \& Raab, 2020, p. 14), meaning that alleged migration-induced problems served as a vehicle for the articulation of far-right attitudes and ideology by some of the participants. This was not rejected by institutional actors, as I will explore in the remainder of this article.

\section{2. 'Tolerating' the Far-Right as a 'Democratic Gesture'}

The municipal government's idea to 'take people's worries seriously' often legitimised far-right agendas. I illustrate this process, shedding light onto the three mechanisms of far-right contestations explored previously, i.e., a dichotomous world views, the emotionalization of societal problems, and a control paradigm.

First, in both neighbourhoods, a recurring theme was the differentiation between 'us' and 'them.' I interpret this as purposeful 'othering' of migrants (Hall, 2006, p. 47) or the 'political elite' (Heitmeyer, 2018) to defend the privileges of the established majority group. For example, refugees are continuously referred to negatively by long-term residents and institutional actors alike. This took various forms, with civil servants portraying refugees as a financial burden to the city and long-term residents propagating stereotypes such as unlawful behaviour or their 'backward' Muslim culture. In Sachsendorf, this is illustrated by an openly racist statement: "The Islamic State has gotten its claws into Cottbus. Muslim youth gangs have staged an uprising and have tried to divide Cottbus among themselves" (Citizens' Dialogue, Sachsendorf).

This contribution shows the construction and devaluation of a homogenous, essentially 'alien' group that is rejected based on ascribed negative characteristics held to be incompatibly with the majority 'we' (Radvan \& Raab, 2020, p. 25). This occurs through the homogenisation and imagination of a group of young people as Muslim 'gang' accused of Islamist violence, echoing the growing prominence of Islamophobia in Europe (Wolfreys, 2018). Additionally, many participants blame the federal government for the city's alleged problem with migration. In both instances, city officials actively support this narrative: For example, a civil servant from the department of social affairs insinuated the "duty of immigrants to integrate" (Citizens' Dialogue, Sandow) and the mayor proclaimed multiple times that "frankly, the federal government let us down [in the management of international migration]" (Citizens' Dialogue, Sandow).

This speaks to a second aspect of contestation, namely the emotionalization of migration. Participants in the dialogues stated that they felt threatened by the increasing presence of migrant families, despite there being no evidence for heightened crime rates in Cottbus in correlation with the arrival of refugees. 
However, instead of correcting this line of argument, the organisers encouraged it by underlining that the emotional and subjective perception of residents should be heard. Prompted in an interview about the dangers of euphemising the impact of such racist claims, one moderator replied: "We think facts are our life, but what counts is the subjective and objective sense of security. They only go together; this is what we wanted to recognise at the dialogues" (Interview, July 27, 2020).

Yet, the initiators' desire to create a space where participants can articulate their emotions did not extend to the targets of racist comments. Representatives of the city council actively negated experiences of racism when voiced by refugees themselves (even though these contributions remain rare, see Section 3.2. for an indication of the lack of diversity of participants), as the following exchange illustrates: “Hello, I come from Syria....I've been in Germany for two years and I live in Cottbus....Why do people hate refugees?" (Citizens' Dialogue, Sachsendorf). A representative of the city council answered:

Nobody hates you...we live in a country with humanistic values. This is what I can say in the name of all Germans. Germans are people that are always ready to help and protect....All in all, there is hospitality towards those who really need protection and really try to integrate. (Citizens' Dialogue, Sachsendorf)

Thus, the open question about hate against refugees is denied by a local politician, pointing instead towards abstract claims such as 'humanism' of 'all Germans.' Given the history of far-right violence in Cottbus, this deeply ignorant denial of racist attitudes against refugees fuels and normalises the agenda of far-right actors.

Finally, the municipal government's negotiation of far-right contestations during the dialogues can be illuminated through the way it furthered the far-right's control paradigm. This became apparent when migration was linked to questions of security and order in public spaces: Long-term residents repeatedly lamented the noise of refugee children (Citizens' Dialogue, Sandow) or expressed fear of leaving the house at night due to the presence of newcomers (Citizens' Dialogue, Sachsendorf). The following contribution by a long-term resident exemplifies these concerns, also juxtaposing today's perceived insecurity with an imagined, more orderly past before the arrival of refugees:

When I moved here about 15 years ago, it was possible to leave the pub drunk and walk home at night. Now I wonder what to do in the evening. That is actually a reason to despair, I have to say....What's next?....Should we all carry weapons? (Citizens' Dialogue, Sachsendorf)

Examining how the city administration responded to such claims, it is striking that officials underline their responsibility to ensure security, as the following comment by a civil servant of the Ordnungsamt illuminates: "A clear message: In cooperation with the police, we have the matter under control and are showing strength. Every day" (Citizens' Dialogue, Sachsendorf). Evidently, the intention of such responses is to appease people's fears. However, given the context of such statements, it is highly questionable if evoking a law-and-order rhetoric is an effective strategy to reduce such fears. Moreover, referencing the importance of a strong police presence can be read as implicit confirmation of the residents' statement, furthering the idea of refugees as a threat to the neighbourhood.

\subsection{The Limits of Participatory Urban Governance in Negotiating Far-Right Contestations}

Overall, my analysis shows that the municipality's negotiation of far-right contestations throughout the citizens' dialogues in Cottbus escapes agonistic and communicative approaches to participatory urban governance alike. While the organisers initially used an agonistic understanding of participation to frame the dialogues' open-ended gesture, they also highlighted the need for rational debate. However, throughout the course of the citizens' dialogues in Sachsendorf and Sandow it became clear that the execution of this envisioned format allowed for the disruption of democratic dialogue, as representatives of the city administration and the city council, as well as the moderators, treated far-right contestations as a legitimate aspect of conflict. Crucially, the design of the dialogues as conflictive spaces of 'tolerated disagreement' served to normalise far-right attitudes.

This normalisation occurred through four dimensions, two of which relate to questions of format, while the two others concern matters of content: 1) Apart from designating formal rules regarding the speaking order, organisers did not deem it necessary to lay out democratic principles such as minority rights to guide the participatory format. 2) This was aggravated by the fact that organisers failed to consider the composition of participants when designing the formats; refugee networks in the neighbourhoods were not specifically invited and information about the citizens' dialogues only advertised in the local newspaper and on the city's website, in German. 3) At the content level, organisers did not reject racist comments by participants, and at times even encouraged them. This was legitimised as they repeatedly highlighted the need for long-term residents to articulate their subjective feelings. In doing so, organisers dangerously conflated genuine empathy with the emotionalization of migration. If the municipal government's aim was to engage residents in democratic discourse, the idea of listening to the dissatisfied without clearly objecting to racism appears counterproductive. 4) Finally, the legitimisation of far-right articulations became evident as the organisers' replies to comments by long-term residents reinforced a dichotomous world view (both with 
regards to the 'native we' vs. 'immigrant other' and in relation to the accusation of the 'elites in Berlin,' i.e., the mayor blaming the Federal Republic for the city's alleged problems with international migration) and with regards to the far-right's control paradigm. The latter became clear when residents voiced security concerns linked to the arrival of refugees in both neighbourhoods, which city officials reinforced.

\section{Concluding Thoughts}

To summarise, the aim of this article was to examine how far-right contestations of migration-led societal transformations in cities put established assumptions about participatory processes to the test. Specifically, I focused on the nexus of communicative/agonistic approaches to participation as prominent positions currently discussed in the literature on participatory urban governance. Bringing them into conversation with social science literature about the far right, I showed that contemporary far-right contestations evoke a different set of questions to those usually posed in research on participatory urban governance processes. Those insights illuminated the ideological and organisational heterogeneity of far-right actors, ranging from extreme-right to radicalright positions, and stressed that the far right's participatory agenda in the name of a homogenous imagination of 'the people' is deeply reactionary and incompatible with democratic negotiation. Consequently, scrutinising the case of Cottbus, I argued that the agonistic idea of taming antagonism into agonism in the context of surging far-right contestations is deeply problematic. Framing racist and authoritarian articulations as a legitimate side of the conflict is to vindicate them. Equally so, the communicative ideal of rational debate is profoundly disputable, as it treats far-right articulations as a legitimate side of an argument.

In Cottbus, the municipal government launched citizens' dialogues that combined both these approaches to participatory urban governance in responding to local far-right rallies. Crucially, this new format was introduced at the neighbourhood scale, as existing participatory institutions such as the city council were thought to pose too high a threshold for residents to participate in. Indeed, my analysis shows that the neighbourhood-scale proved to be a fruitful site of negotiation as it helped disentangle the issue of international migration from context-specific socio-spatial problems. In Sachsendorf and Sandow, these problems were implicitly linked to the neighbourhoods histories of reconstruction and demolition. However, the dialogues also served as a platform for far-right positions, as the municipal government and city administration did not reject reactionary claims. In this context, the ideas of agonistic strife and rational consensus building normalised key tenets of far-right politics and disrupted the possibility of democratic dialogue. The municipal government appeared utterly complicit in this process of disruption, as it furthered: 1) a dichotomous worldview in the form of racist language and 'anti-elite' sentiments, 2) the emotionalization of societal problems by framing migration as a security threat, and 3) the installation of a 'control paradigm' that calls for authoritarian politics. Contemplating the metaphor of disruption, it appears that while the power relations inherent to the participatory formats in Cottbus rupture the democratic ideals of theories of participatory urban governance, they also present a certain continuity with critiques of participatory processes.

Thus, to conclude, I contend that municipal leaders need to reconfigure the practice of participation to negotiate contemporary far-right contestations regarding both format and content of such participatory endeavours. In a climate of rising reactionary forces, locating societal negotiations at the neighbourhood level proves productive, as such interventions hold the potential to address the roots of political grievance and disempowerment by recognising past injustices (Bollens, 2012 , p. 235). However, municipalities are urged to reject far-right articulations by conveying the importance of democratic principles themselves. In terms of format, municipalities need to actively seek to include a diversity of participants so that citizens' dialogues represent the views and concerns of all residents in the neighbourhood. This could either be achieved through a closer exchange between the municipal government and neighbourhoodbased community organising when preparing the events or through democratic experiments such as civic lotteries that would ensure the random sampling of participants.

Nevertheless, as I illustrated by analysing the shift that was made in the council meeting, from the municipality's focus on the far right to concentrating on the issue of trust between long-term residents and the city government, it is striking how there was almost no effort to address those most vulnerable to, and/or suffering from, far-right attacks in the city. This could be achieved, for instance, by considering local meetings where municipal actors specifically listen to the targets of far-right attacks, attempting to mobilise a different emotional register, one that recognises the harmful consequences of far-right contestations. Regarding content, municipal governments need to design guiding parameters of dialogue that address the limits of democratic content, i.e., that protect against all kinds of discrimination as a precondition of participation. This also entails designing participatory settings in such a way that participants are comfortable and recognise it as a(n) (un-)learning process and are open to the revision of previously held standpoints. Finally, negotiating far-right contestations takes the courage to endure antagonism in case participants refuse to give up far-right positions. Otherwise, 'hostile democracy' (Süß \& Kolioulis, 2020) prevails.

\section{Acknowledgments}

I am grateful to research participants in Cottbus, without whom this research would not be possible. This article 
is part of my PhD project and I thank my supervisors Matthias Bernt and Laura Calbet i Elias for commenting on earlier drafts. Equally, I thank the three anonymous reviewers for taking the time to read my manuscript and for providing constructive comments as well as the editors for creating such a smooth publication process.

\section{Conflict of Interests}

The author declares no conflict of interests.

\section{References}

Amin, A. (2002). Ethnicity and the multicultural city: Living with diversity. Environment and Planning A: Economy and Space, 34(6), 959-980.

Arnstein, S. R. (1969). A ladder of citizen participation. JAIP, 35(4), 216-224.

Bäcklund, P., \& Mäntysalo, R. (2010). Agonism and institutional ambiguity: Ideas on democracy and the role of participation in the development of planning theory and practice: The case of Finland. Planning Theory, 9(4), 333-350.

Barney, D. D., \& Laycock, D. (1999). Right-populists and plebiscitary politics in Canada. Party Politics, 5(3), 317-339.

Beaumont, J., \& Loopmans, M. (2008). Towards radicalized communicative rationality: Resident involvement and urban democracy in Rotterdam and Antwerp. International Journal of Urban and Regional Research, 32(1), 95-113.

Beaumont, J., \& Nicholls, W. (2008). Plural governance, participation and democracy in cities. International Journal of Urban and Regional Research, 32(1), 87-94.

Bernt, M. (2009). Partnerships for demolition: The governance of urban renewal in East Germany's shrinking cities. International Journal of Urban and Regional Research, 33(3), 754-769.

Bollens, S. A. (2012). City and soul in divided societies (1st ed.). London and New York, NY: Routledge.

Bond, S. (2011). Negotiating a 'democratic ethos': Moving beyond the agonistic: Communicative divide. Planning Theory, 10(2), 161-186.

Botsch, G., \& Schulze, C. (2018, June). Die Sprache der 'Asylkritik': Eine Analyse der Reden bei ZukunftHeimat-Kundgebungen in Cottbus [The language of 'asylum criticism': An analysis of the speeches at Zukunft Heimat rallies in Cottbus]. Moses Mendelssohn Zentrum. Retrieved from https://www. mmz-potsdam.de/meldung-lesen/items/ejgfstudie-zu-reden-bei-den-cottbuser-zukunft-heimatkundgebungen.html

Brady, K. (2018, January 25). German city of Cottbus grapples with violence between locals and refugees. Deutsche Welle. Retrieved from https://www.dw. com/en/german-city-of-cottbus-grapples-withviolence-between-locals-and-refugees/a-42309934
Buck, T. (2018, February 2). German police flex muscles to calm Cottbus refugee tensions. Financial Times. Retrieved from https://www.ft.com/content/ b97b0fc2-0753-11e8-9650-9c0ad2d7c5b5

Canovan, M. (1999). Trust the people! Populism and the two faces of democracy. Political Studies, 47(1), 2-16.

Canovan, M. (2002). Taking politics to the people: Populism as the ideology of democracy. In Y. Mény \& Y. Surel (Eds.), Democracies and the populist challenge (pp. 25-44). London: Palgrave Macmillan.

Castelli Gattinara, P., \& Pirro, A. L. P. (2019). The far right as social movement. European Societies, 21(4), 447-462.

Cooke, B., \& Kothari, U. (Eds.). (2001). Participation: The new tyranny? London: Zed Books.

Cornwall, A. (2002). Locating citizen participation. IDS Bulletin, 33(2), $\mathrm{i}-\mathrm{x}$.

DIFU. (2019). Bürgerdialog in Zeiten aufgeheizter Debatten [Citizens' dialogues in times of heated debate]. Deutsches Institut Für Urbanistik. Retrieved from https://difu.de/veranstaltungen/2019-12-12/ buergerdialog-in-zeiten-aufgeheizter-debatten

El-Kayed, N., Bernt, M., Hamann, U., \& Pilz, M. (2020). Peripheral estates as arrival spaces? Conceptualising research on arrival functions of new immigrant destinations. Urban Planning, 5(3), 113-114.

Emcke, C. (1999). Der braune Alltag [The everyday life of Nazis]. Der Spiegel. Retrieved from https://www. spiegel.de/spiegel/print/d-13666852.html

Fainstein. (1999). Can we make the cities we want? In R. A. Beauregard \& S. Body-Gendrot (Eds.), The urban moment: Cosmopolitan essays on the late-20thcentury city: Vol: Urban affairs annual reviews (pp. 249-272). Thousand Oaks, CA: Sage Publications.

Fainstein, S. (2010). The just city. Ithaca, NY: Cornell University Press.

Flyvbjerg, B. (1996). The dark side of planning: Rationality and 'realrationalität.' In S. J. Mandelbaum, L. Mazza, \& R. W. Burchell (Eds.), Explorations in planning theory (pp. 383-394). New York, NY: Routledge.

Forester, J. (1989). Planning in the face of power. Berkeley, CA: University of California Press.

Förtner, M., Belina, B., \& Naumann, M. (2020). The revenge of the village? The geography of right-wing populist electoral success, anti-politics, and austerity in Germany. Environment and Planning C: Politics and Space. Advance online publication. https://doi.org/ 10.1177/2399654420951803

Frediani, A. A., \& Cociña, C. (2019). 'Participation as planning': Strategies from the south to challenge the limits of planning. Built Environment, 45(2), 143-161.

Froio, C., Gattinara, P. C., Bulli, G., \& Albanese, M. (2020). CasaPound Italia: Contemporary extreme-right politics. London: Routledge.

Fröschner, J., \& Warnecke, J. (2019). 'Was interessiert mich denn Cottbus' Dynamiken rechter Formierung in Südbrandenburg: Der Verein Zukunft Heimat ["Why 
care about Cottbus" Dynamics of far-right formations in Southern Brandenburg: Zukunft Heimat]. Berlin: Rosa Luxemburg Stiftung and Aktionsbündnis Brandenburg.

German Federal Agency for Cartography and Geodesy. (2021). Free downloads: Open data. German Federal Agency for Cartography and Geodesy. Retrieved from https://www.bkg.bund.de/EN/Home/home.html

Grubbauer, M., \& Kusiak, J. (2012). Introduction: Chasing Warsaw. In M. Grubbauer \& J. Kusiak (Eds.), Chasing Warsaw: Socio-material dynamics of urban change since 1990 (pp. 9-24). Frankfurt and New York, NY: Campus.

Gualini, E. (Ed.). (2015). Planning and conflict: Critical perspectives on contentious urban developments. London and New York, NY: Routledge.

Hall, S. (2006). Cosmopolitan promises, multicultural realities. In R. Scholar (Ed.), Divided cities: The Oxford amnesty lectures 2003 (pp. 20-51). Oxford: Oxford University Press.

Healey, P. (1992). Planning through debate: The communicative turn in planning theory. The Town Planning Review, 63(2), 143-162.

Heitmeyer, W. (2018). Autoritäre Versuchungen [Authoritarian temptations] (3rd ed.). Berlin: Suhrkamp.

Huxley, M., \& Yiftachel, O. (2000). New paradigm or old myopia? Unsettling the communicative turn in planning theory. Journal of Planning Education and Research, 19(4), 333-342.

IASS. (2018). Social transformation and policy advice in Lusatia. Institute for Advanced Sustainability Studies Potsdam. Retrieved from https://www.iasspotsdam.de/en/research/sociostructural-changepolicy-advice-lusatia

Innes, J. E., \& Booher, D. E. (2004). Reframing public participation: Strategies for the 21st century. Planning Theory \& Practice, 5(4), 419-436.

Kabisch, S., \& Peter, A. (2014). Quartiere auf Zeit [Temporary neighbourhoods]. In O. Schnur (Ed.), Quartiersforschung: Zwischen Theorie und Praxis [Neighbourhood research: Between theory and practice] (pp. 301-318). Heidelberg: Springer.

Khakee, A. (2020). Planning dilemmas. Planning Theory \& Practice, 21(1), 175-181.

Legacy, C., Metzger, J., Steele, W., \& Gualini, E. (2019). Beyond the post-political: Exploring the relational and situated dynamics of consensus and conflict in planning. Planning Theory, 18(3), 273-281.

Liebmann, H., Hagemeister, U., Haller, C., \& Nelle, A. (2010). 4. Statusbericht Stadtumbau vor neuen Herausforderungen [4th report on new challenges for Stadtumbau]. Erkner: Bunderstransferstelle Stadtumbau Ost.

Miessen, M. (2011). The nightmare of participation: Crossbench praxis as a mode of criticality. Berlin: Sternberg Press.

Miraftab, F. (2019). Insurgent practices and decolonization of future(s). In M. Gunder, A. Madanipour, \& V.
Watson (Eds.), The Routledge handbook of planning theory (pp. 276-288). London: Routledge.

Mondon, A., \& Winter, A. (2020). Reactionary democracy: How racism and the populist far right became mainstream. London: Verso Books.

Mouffe, C. (2000). The democratic paradox. London: Verso Books.

Mudde, C. (2007). Populist radical right parties in Europe. Cambridge: Cambridge University Press.

Mudde, C. (2019). The far right today. Cambridge: Polity.

Nettelbladt, G., \& Reichle, L. R. (in press). Proximity and distance: Navigating a field of tension in urban qualitative research on the German far right during COVID-19. IJURR Spotlight On "PhD Research during a Pandemic."

Opferperspektive. (2021). Übersicht: Statistik rechter Gewalttaten in Brandenburg [Overview: Statistics on far-right violent attacks in Brandenburg]. Opferperspektive. Retrieved from https://www. opferperspektive.de/rechte-angriffe/statistikbrandenburg/statistik-rechter-gewalttaten-inbrandenburg-2

Paxton, F. (2019). Towards a populist local democracy? The consequences of populist radical right local government leadership in Western Europe. Representation, 56(3), 411-430.

Pløger, J. (2004). Strife: Urban planning and agonism. Planning Theory, 3(1), 71-92.

Purcell, M. (2006). Urban democracy and the local trap. Urban Studies, 43(11), 1921-1941.

Purcell, M. (2009). Resisting neoliberalization: Communicative planning or counter-hegemonic movements? Planning Theory, 8(2), 140-165.

Radvan, H., \& Raab, M. (2020). Dialog-Veranstaltungen als Demokratisierung? Eine Analyse der Bürgerdialoge in Cottbus in Zeiten völkisch-autoritärer Mobilisierung [Dialogue as democratisation? Analysing neighbourhood forums during völkischauthoritarian mobilisation] (MIKOWA Working Paper No. 1). Cottbus: BTU.

Rafael, S. (2018, February 14). Was in Cottbus verkehrt läuft: Und was sich daraus lernen lässt [What's going wrong in Cottbus and lessons to be learnt]. Belltower. Retrieved from https://www.belltower.news/wasin-cottbus-verkehrt-laeuft-und-was-sich-darauslernen-laesst-47008

Rivero, J. J., Sotomayor, L., Zanotto, J. M., \& Zitcer, A. (2020). Democratic public or populist rabble: Repositioning the city amidst social fracture. International Journal of Urban and Regional Research. Advance online publication. https://doi.org/10.1111/14682427.12898

Roy, A. (2009). Civic governmentality: The politics of inclusion in Beirut and Mumbai. Antipode, 41(1), 159-179.

Rucht, D. (2018). Mobilization against refugees and asylum seekers in Germany: A social movement perspective. In S. Rosenberger, V. Stern, \& N. Merhaut (Eds.), 
Protest movements in asylum and deportation (pp. 225-245). Basel: Springer International Publishing.

Stadt Cottbus. (2018). Stadtteilgespräche Mai/Juni 2018. Bürgerdialoge [Neighbourhood forums May/June 2018. Citizens' dialogues]. Stadt Cottbus. Retrieved from https://www.cottbus.de/aktuelles/dialoge/ stadtteilgespraeche_mai_juni_2018.html

Stadt Cottbus. (2019a). Arbeitsmarkt: Cottbus in Zahlen [Labour market: Statistics in Cottbus]. Statistikstelle Stadt Cottbus. Retrieved from https:// www.cottbus.de/verwaltung/gb_ii/buergerservice/ statistik/arbeitsmarkt.html

Stadt Cottbus. (2019b). Bevölkerung: Cottbus in Zahlen [Population: Statistics in Cottbus]. Statistikstelle Stadt Cottbus. Retrieved from https://www. cottbus.de/verwaltung/gb_ii/buergerservice/ statistik/bevoelkerung.html

Stadt Cottbus. (2019c). Integriertes Stadtentwicklungskonzept (INSEK) Cottbus 2035 [Integrated urban development concept (INSEK) Cottbus 2035]. Stadt Cottbus. Retrieved from https://www.cottbus. de/verwaltung/gb_iv/stadtentwicklung/insek

Stadt Cottbus. (2019d). Wahl der Stadtverordnetenversammlung Cottbus [Municipal elections Cottbus]. Stadt Cottbus. Retrieved from https://www.cottbus. de/verwaltung/gb_ii/buergerservice/wahlen/wahl_ der_stadtverordnetenversammlung_cottbus.html

Süß, R., \& Kolioulis, A. (2020). The politics of provocations against hostile institutions. BREAK LINE. Retrieved from https://breakline.studio/projects/hostiledemocracy

Swyngedouw, E. (2011). Interrogating post-democratization: Reclaiming egalitarian political spaces. Political Geography, 30(7), 370-380.

Van Wymeersch, E., Oosterlynck, S., \& Vanoutrive, T. (2019). The political ambivalences of participatory planning initiatives. Planning Theory, 18(3), 359-381.

Verloo, N. (2018). Governing the global locally: Agonistic democracy practices in The Hague's Schilderswijk. Urban Studies, 55(11), 2354-2371.

Wilson, J., \& Swyngedouw, E. (Eds.). (2015). The postpolitical and its discontents: Space of depoliticisation, spectres of radical politics. Edinburgh: Edinburgh University Press.

Wolfreys, J. (2018). Republic of Islamophobia: The rise of respectable racism in France. Oxford and New York, NY: Oxford University Press.

Yin, R. K. (2014). Case study research: Design and methods (5th ed.). Thousand Oaks, CA: Sage Publications.

\section{About the Author}

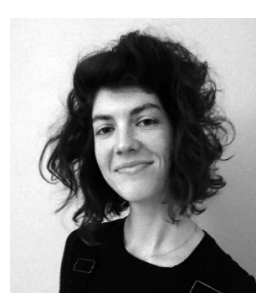

Gala Nettelbladt is a PhD Candidate at the Institute for Social Sciences, Humboldt-University of Berlin and Research Associate at the Leibniz Institute for Research on Society and Space (IRS) with a dual background in Social Sciences and Urban Planning. Her PhD project investigates the urban politics of far-right contestations in planning and governance processes. 